\title{
Six Degrees of Separation: from derivative suits to shareholder class actions
}

\author{
Seis Graus de Separação: das ações derivativas às ações coletivas de acionistas
}

\author{
Ángel R. Oquendo \\ University of Connecticut School of Law - State of Connecticut, USA
}

\begin{abstract}
: trans-individual litigation has revolutionized modern law. Specifically, corporate law has partaken in this phenomenon. For instance, derivative suits allow individuals to sue for a large collectivity in relation to corporate matters. This paper aims to analyze this derivative suits, comparing then to shareholder class actions, explaining that the two procedures resemble each other only superficially and that they diverge from each other on a more profound level. Derivative suits aim at the vindication of a genuinely collective and indivisible right, while shareholder class actions seek to enforce an aggregation of individual entitlements. Consequently, these mechanisms also differ in the kind of representation they entail, in the objective they pursue, in how they construct fairness internally, and in how they approach the central problem of adequacy of representation. An appreciation of this dichotomy contributes to an understanding not only of the inner workings of each of these two devices but also of the corporation itself and of the relationship among the corporate entity, the board of directors, the investors, and even the stakeholders. In addition, it suggests the need for a new interpretation of the key distinction between both actions one should focus on the nature of the right at stake.
\end{abstract}

Keywords: Trans-individual Litigation. Derivative Suits. Shareholder Class Actions.

Recebido em: 09/06/2016

Revisado em: 12/07/2016

Aprovado em: 19/07/2016
Resumo: as ações transindividuais revolucionaram o direito contemporâneo. Especificamente, o direito empresarial tomou parte neste fenômeno. Por exemplo, na ação derivativa, indivíduos - os acionistas - estão legitimados a litigar em nome de uma coletividade, em relação a assuntos da corporação. O objetivo deste artigo é analisar essa ação derivativa, comparando-as com as ações coletivas de acionistas em geral, explicitando que os dois procedimentos detêm apenas similitudes superficiais, mas divergem em nível mais profundo. A ação derivativa objetiva a proteção de um genuíno direito coletivo e indivisível, enquanto as demais ações coletivas de acionistas asseguram uma agregação de direitos individuais. Consequentemente, diferem na forma de representação, sobretudo em sua adequação, na equidade interna do procedimento e no objetivo que perseguem. O estudo dessa dicotomia contribui não só na compreensão dessas duas formas de processo, mas no entendimento da própria corporação e a relação entre ela e a sua diretoria, investidores e mesmo os demais stakeholders. No mais, sugere-se a necessidade de uma nova interpretação para a distinção entre as citadas ações, considerando a natureza do direito em jogo.

Palavras-chave: Litígios Transindividuais. Ações Derivativas. Ações Coletivas de Acionistas. 


\section{Introduction}

Trans-individual litigation has revolutionized modern law. It has radically altered the manner of assertion and adjudication of legal claims. Beyond concerning a large number of people, the underlying suits operate in a unique fashion. In particular, they call for the constant protection of the interests of the parties on whose behalf the plaintiffs purport to speak.

Not surprisingly, corporate law has partaken in this phenomenon. For instance, derivative suits allow individuals to sue for a larger collectivity, somewhat along the lines of the citizen suits established over a century later. Of course, they turn on the claims of the corporation, rather than those of the society as a whole. Likewise, stockholders have deployed the class action, since its inception, to aggregate their claims specifically against the corporate entity or the board of directors.

This Article will concentrate on derivative suits and shareholder class actions. It will ultimately contend that the two procedures resemble each other only superficially and that they diverge from each other on a more profound level. Most significantly, derivative suits aim at the vindication of a genuinely collective and indivisible right, while shareholder class actions seek to enforce an aggregation of individual entitlements. Consequently, these mechanisms also differ in the kind of representation they entail, in the objective they pursue, in how they construct fairness internally, and in how they approach the central problem of adequacy of representation.

An appreciation of this dichotomy contributes to an understanding not only of the inner workings of each of these two devices but also of the corporation itself and of the relationship among the corporate entity, the board of directors, the investors, and even the stakeholders. In addition, it suggests the need for a new interpretation of the key distinction, everpresent in the case law, between derivative and direct corporate claims. Accordingly, in order to distinguish the former from the latter, courts should focus, first and foremost, on the nature of the right at stake, following the path delineated in Part IV. At the end of the day, by grasping 
the difference between derivative suits and shareholder class actions, one gains invaluable insights into group rights generally.

Part II will evoke an initial view, according to which the two procedures at stake as coincide in their essence and differ only in their technical details. Part III, in turn, will propose an alternative conception, according to which the two devices converge only formally, yet diverge critically. Finally, drawing on this second outlook, Parts IV and V will, respectively, recast the distinction between derivative and direct suits and re-conceptualize collective entitlements.

\section{An Initial View}

On first impression, one might view derivative suits and shareholder class actions as essentially similar. In particular, one might regard them as collective procedures that similarly serve to vindicate the group rights of stockholders. Accordingly, both procedural devices allow one or several corporate investors to litigate on behalf of the collectivity.

Someone taking this approach might maintain that these two types of litigation similarly seek to correct managerial failure. She might add that the judge must simply resolve a dispute as to whether the managers indeed failed to protect the entitlements of the shareholders. Thus construed, both procedural mechanisms resemble each other not only in how they operate but also in what they ultimately pursue.

From this perspective, derivative suits and shareholder class actions enable, along parallel lines, an extraordinary alteration in the status quo to take place. Specifically, they empower an individual investor to displace the directorate as the speaker for shareholders as a group, whether conceived as the corporation itself or as a self-standing class. Ordinarily, the board possesses the prerogative to speak for the corporate entity and to care for the stockholders' economic well-being.

The relevant procedural parameters tend to reinforce this standpoint. For instance, Rule 23.1 of the Federal Rules of Civil Procedure empowers "[...] one or more shareholders [...] to bring a derivative action to enforce 
a right" of "the corporation". It explicitly requires that the plaintiffs "[...] fairly and adequately represent the interests of shareholders [...] who are similarly situated"2. Rule 23 , in turn, entitles "[o]ne or more members of a class," including a stockholder class, to "[...] sue [...] on behalf of all members"3. It expressly demands that "[ $[.$.$] the representative parties [\ldots]$ fairly and adequately protect the interests of the class"

Of course, Rule 23.1 zeroes in on the entitlements of the corporation, while Rule 23 focuses, in the context of corporate law, on the rights of the individual investors. Nonetheless, both provisions suggest that the nominal claimants act in representation of the interests of the shareholders. This convergence should not come as a surprise because, in a sense, a corporation possesses no interests of its own other than those of its stockholders.

Consistently, both rules compel the plaintiff to secure judicial endorsement prior to settling, voluntarily dismissing, or compromising the claim ${ }^{5}$. Thus, they evidently seek to protect the entitlements of other, absent investors. In fact, the complainant in a derivative suit must transmit "[n]otice of [the] proposed settlement, voluntary dismissal or compromise [...] to shareholders [...] in the manner that the court orders". Likewise, the representative party in a class action must send "[...] notice in a reasonable manner to all class members who would be bound by the proposal"?

While premised on the overall convergence between the two types of litigation, the position under consideration could easily recognize certain undeniable "technical" dissimilarities. First, different rules

\footnotetext{
${ }^{1}$ Fed. R. Civ. P. 23.1(a).

${ }^{2}$ Id. According to the Advisory Committee, this "sentence recognizes that the question of adequacy of representation may arise when the plaintiff is one of a group of shareholders or members.” Fed. R. Civ. P. 23.1 advisory committee's note (1966 Amendment).

${ }^{3}$ Fed. R. Civ. P. 23(a).

${ }^{4}$ Fed. R. Civ. P. 23(a)(4).

${ }^{5}$ Fed. R. Civ. P. 23.1(c); Fed. R. Civ. P. 23(e).

${ }^{6}$ Fed. R. Civ. P. 23.1(c).

${ }^{7}$ Fed. R. Civ. P. 23(e)(1).
} 
govern each of these procedures: in federal court, for instance, Rule 23.1 applies to derivative suits and Rule 23 applies to class actions. While these provisions overlap on the points just discussed, they differ in many of their details.

In particular, the pleading requirements vary. In derivative suits, for instance, plaintiffs must verify the complaint ${ }^{8}$. In shareholder class actions, in contrast, they need not do so". Nonetheless, the claimants in a shareholder class action must "provide a sworn certification" declaring, inter alia, that they "reviewed" the filing, that they did not "purchase" their stock "at the direction of" their attorney or for purposes of litigation, that they will not receive any compensation for serving as a representative party, and whether they have recently lodged any other class actions ${ }^{10}$. Finally, the plaintiff must, when suing derivatively - but not when litigating on behalf of a class - make special allegations as to share ownership, ${ }^{11}$ as to the absence of "collusive" intent, ${ }^{12}$ and as to "any effort to obtain the desired action from the directors"13.

Case law has interpreted this last pre-requisite to mean that complainants in a derivative suit, as opposed to a shareholder class action, must first "exhaust [...] intracorporate remedies" 14 . In other words, the plaintiffs must request the directorial board to pursue the claim, unless they show the futility of any such demand in light of the body's conflict of interest ${ }^{15}$. With such a request, they constructively

${ }^{8}$ Fed. R. Civ. P. 23.1(b) ("The complaint must be verified [...]").

${ }^{9}$ See Fed. R. Civ. P. 11(a) ("Unless a rule or statute specifically states otherwise, a pleading need not be verified or accompanied by an affidavit").

${ }^{10} 15$ U.S.C. $\$ 77 z-1(a)(2)$ (2006) (Private Securities Litigation Reform Act).

${ }^{11}$ Fed. R. Civ. P. 23.1(b)(1). See also Del. Ct. Ch. R. 23.1(a); Del. Code Ann. tit. 8, § 327 (West 2011).

${ }^{12}$ Fed. R. Civ. P. 23.1(b)(2).

${ }^{13}$ Fed. R. Civ. P. 23.1(b)(3) See also Del. Ct. Ch. R. 23.1(a)

${ }^{14}$ Aronson v. Lewis, 473 A.2d 805, 811 (Del. 1984), overruled on other grounds by Brehm v. Eisner, 746 A.2d 244 (Del. 2000).

15 Beam v. Stewart, 845 A.2d 1040, 1048 (Del. 2004) (A "stockholder may not pursue a derivative suit to assert a claim of the corporation unless: (a) she has first demanded that the directors pursue the corporate claim and they have wrongfully refused to do so; 
concede the directors' "independence" 16 and may proceed only if they demonstrate a "wrongful refusal"17.

Courts have thus pushed derivative suits away from the noticepleading model that prevails in class actions and in litigation as a whole ${ }^{18}$. Indeed, they have essentially forbidden plaintiffs to lodge a complaint that merely notifies the defendant of the claim and to build their case through discovery ${ }^{19}$. When suing derivatively, complainants must, in effect, either make their case upfront or else face early dismissal. Specifically, they "must allege with particularity facts raising a reasonable doubt that the corporate action being questioned was properly the product of business judgment" 20 .

or (b) such demand is excused because the directors are deemed incapable of making an impartial decision regarding the pursuit of the litigation").

${ }^{16}$ Levine v. Smith, 591 A.2d 194, 212 (Del. 1991), overruled on other grounds by Brehm v. Eisner, 746 A.2d 244 (Del. 2000).

${ }^{17} I d$. at 200.

${ }^{18}$ See $i d$. at 210 ("Rule 23.1 is an exception to the general notice pleading standard of the Rules."); see also Brehm v. Eisner, 746 A.2d 244, 254 (Del. 2000) ("Pleadings in derivative suits are governed by Chancery Rule $23.1 \ldots$. Those pleadings must comply with stringent requirements of factual particularity that differ substantially from the permissive notice pleadings governed solely by Chancery Rule $8(\mathrm{a})$. Rule 23.1 is not satisfied by conclusory statements or mere notice pleading.”). Cf. Fed. R. Civ. P. 8(a)(2) ("A pleading that states a claim for relief must contain ... a short and plain statement of the claim showing that the pleader is entitled to relief."). "The liberal notice pleading of Rule 8(a)," according to the United States Supreme Court, "is the starting point of a simplified pleading system, which was adopted to focus litigation on the merits of a claim." Swierkiewicz v. Sorema N.A., 534 U.S. 506, 514 (2002). "Other provisions of the Federal Rules of Civil Procedure are inextricably linked to Rule 8(a)'s simplified notice pleading standard." Id. at 513. "This simplified notice pleading standard relies on liberal discovery rules and summary judgment motions to define disputed facts and issues and to dispose of unmeritorious claims." Id. at 512.

${ }^{19}$ See, e.g., Levine v. Smith, 591 A.2d 194, 211 (Del. 1991) (explaining that allowing a plaintiff whose complaint does not contain particularized allegations to conduce discovery "would be a complete abrogation of the principles underlying the pleading requirements of Rule 23.1.”).

${ }^{20}$ Brehm v. Eisner, 746 A.2d 244, 254-255 (Del. 2000). 
In contrast, litigants filing class actions and other suits need not present "detailed factual allegations" 21 . All the same, they must plead, at least in federal tribunals, "factual content that allows the court to draw the reasonable inference" of liability ${ }^{22}$. Certainly, this last requirement considerably thickens the "notice" that the defendants must receive. It does not imply, however, that the plaintiffs must allege the facts "with particularity."

More generally, derivative suits diverge from class actions, according to the Delaware Supreme Court, with respect to both the locus of the injury and the beneficiary of the remedy ${ }^{23}$. As previously pointed out, derivative suits stake corporate rather than shareholder claims. Therefore, they involve harm to and relief for the corporation, in the first instance ${ }^{24}$. Of course, the damage and the reparation indirectly and ultimately concern the investors as the residual owners. Shareholder direct actions, for their part, concentrate from the outset on injuries to and on remedies for the stockholders ${ }^{25}$.

${ }^{21}$ Bell Atl. Corp. v. Twombly, 550 U.S. 544, 555 (2007). In Ashcroft v. Iqbal, the U.S. Supreme Court held that "the pleading standard Rule 8 announces does not require 'detailed factual allegations,' but it demands more than an unadorned, the-defendantunlawfully-harmed-me accusation.” 556 U.S. 662, 678 (2009) (quoting Bell Atl. Corp., 550 U.S. at 555).

${ }^{22}$ Ashcroft v. Iqbal, 556 U.S. 662, 678 (2009). The claim must have "facial plausibility," in the sense that "the plaintiff pleads factual content that allows the court to draw the reasonable inference that the defendant is liable for the misconduct alleged." Id.

${ }^{23}$ Derivative suits differ not only from shareholder class actions but also from direct actions, in general, as far as "(1) who suffered the alleged harm (the corporation or the suing stockholders, individually); and (2) who would receive the benefit of any recovery or other remedy (the corporation or the stockholders, individually." Tooley v Donaldson, Lufkin \& Jenrette, Inc., 845 A2d 1031, 1033 (Del. 2004). See also Ams. Mining Corp. v. Theriault, 51 A.3d 1213, 1264-1265 (Del. 2012).

${ }^{24}$ See Aronson v. Lewis, 473 A.2d 805, 811 (Del. 1984), overruled on other grounds by Brehm v. Eisner, 746 A.2d 244 (Del. 2000). ("The derivative action . . . is a suit by the corporation, asserted by the shareholders on its behalf, against those liable to it.").

${ }^{25}$ See generally infra, Part IV. 


\section{An Alternative View}

Against the initial view just delineated, an alternative conception suggests itself. In fact, it leads to a diametrically opposed approach. From this perspective, as explained and defended in this Part, derivative suits and shareholder class actions converge formally but diverge critically.

On the formal front, both procedures unfold collectively. More precisely, they operate trans-individually, insofar as they do not concern an individual but rather a larger group ${ }^{26}$. Hence, derivative suits deal with the entitlements of the corporation, not of the complainant. Likewise, shareholder class actions involve the rights of all stockholders, not just those of the party pursuing the litigation.

Secondly, the two types of litigation involve representation. The nominal claimants generally vindicate the entitlements of others. In particular, they represent the corporation in derivative suits and large number of corporate investors in shareholder class actions ${ }^{27}$.

Thirdly, both procedural mechanisms coincide formally on the instrumental objective of resolving a dispute between stockholders and directors ${ }^{28}$. They also overlap in terms of their reflexive or intrinsic aim, which consists in allowing investors and managers to interact throughout the proceedings in terms of fairness ${ }^{29}$. Of course, the litigation itself

\footnotetext{
${ }^{26}$ See supra notes 2, 3, 4 and accompanying text.

${ }^{27}$ See supra notes 1, 3, 24 and accompanying text.

${ }^{28} \mathrm{See}$ Fed. R. Civ. P. 23.1(a) ("This rule applies when one or more shareholders or members of a corporation ... bring a derivative action to enforce a right that the corporation ... may properly assert but has failed to enforce"); Fed. R. Civ. P. 23 advisory committee's note (1966 Amendment) ("[A]ctions by shareholders to compel the declaration of a dividend[,] the proper recognition and handling of redemption or pre-emption rights, or the like... should ordinarily be conducted as class actions").

${ }^{29}$ See Ángel R. Oquendo, The Comparative and the Critical Perspective in International Agreements, 15 UCLA Pac. Basin L.J. 205, 208 (1997) ("[Contrary to an] exclusively instrumental view, according to which procedure is taken to serve particular ends [...]. a reflexive conception ... regards procedure as having intrinsic value. The value of procedure [is] thus ... a function of not only the objectives advanced but also the internal constitution of procedure-e.g., how it processes the arguments made, how it treats the various actors, what kind of power relations it supports.").
} 
usually becomes an important part of and, therefore, colors the entire relationship between these actors.

Finally, the two procedural devices confront the same primary challenge. In other words, they must guarantee adequacy of representation. The plaintiffs must clearly and consistently show that they are adequately representing the relevant group, whether the corporation or the class of stockholders ${ }^{30}$.

Despite converging from a formal standpoint, however, these procedures diverge at a more fundamental level. Actually, the referenced points of convergence reveal themselves as points of divergence upon deeper inspection. As the United States Supreme Court declared in its 1881 opinion in Hawes $v$. Oakland, ${ }^{31}$ a derivative suit "[...] is a very different affair from a controversy between the shareholder of a corporation and that corporation itself, or its managing directors or trustees, or the other shareholders, who may be violating his rights or destroying the property in which he has an interest" 32 . Of course, the disparity does not disappear when the comparison involves, on the second end, a complaint filed not by one stockholder, but rather by a multiplicity thereof.

\subsection{Collective Litigation}

First, the two types of litigation indeed proceed collectively, but in quite dissimilar ways. Derivative suits are genuinely collective because they involve a collectivity (i.e., the corporation, as the real party in interest, as well as its rights) $)^{33}$. In contrast, shareholder class actions paradigmatically aggregate numerous individual claims. Consequently, they concern individuals and unfold collectively only inasmuch as they affect the entitlements of an aggregation of parties, instead of those of

\footnotetext{
${ }^{30}$ See supra notes 1, 2, 4 and accompanying text.

${ }^{31} 104$ U.S. 450 (1881), abrogated by Kamen v. Kemper Fin. Servs., Inc., 500 U.S. 90 (1991).

${ }^{32} I d$. at 454 (1881).

33 See Zapata Corp. v. Maldonado, 430 A.2d 779, 784 (Del. 1981) ("Derivative suits enforce corporate rights and any recovery obtained goes to the corporation").
} 
a single person or entity 34 . "In law," the United States Supreme Court has proclaimed, "[...] the corporation and the aggregate members of the corporation are not the same thing $[\ldots]^{\prime 3} 35$.

Of course, the corporation has no life of its own. Its interests often boil down to those of the investors, who residually and ultimately own the entity. Therefore, a complaint on behalf of the corporation may not differ much, in a sense, from a complaint in the name of each one of the stockholders.

Nonetheless, the corporation normally also embodies the interest of many stakeholders, such as its creditors, its employees, its suppliers, or the communities in which it operates ${ }^{36}$. Ideally, a

${ }^{34}$ Some commentators have proposed treating the class as an entity for practical reasons.
For instance, Edward Cooper contends that such doing so "may help to sharpen the focus
on class-as-client, speaking through one set of agents to another." Edward H. Cooper,
Rule 23: Challenges to the Rulemaking Process, 71 N.Y.U. L. REV. 13, 16. (1996). He maintains that this approach would additionally enable courts to decide, in a more clearheaded fashion, issues of "mootness," counsel conflict of interest, "jurisdiction," "due process," "choice of law," "adequacy of settlement," "preclusion." Id. 28-29. See also David L. Shapiro, Class Actions: The Class as Party and Client, 73 Notre Dame L. Rev. 913, 917 (1998) (arguing that the class action "should be viewed as not involving the claimants as a number of individuals, or even as an 'aggregation' of individuals, but rather as an entity in itself for the critical purposes of determining the nature of the lawsuit").

${ }^{35}$ Hawes, 104 U.S. at 455 (quoting Foss v. Harbottle, [1843] 2 Hare, 461).

${ }^{36}$ See, e.g., 15 Pa. Cons. Stat. Ann. $§ 1715$ (a)(1) (West 2013) ("[The directors] may . . . consider [t]he effects of any action upon any or all groups affected by such action, including shareholders, employees, suppliers, customers and creditors of the corporation, and upon communities in which offices or other establishments of the corporation are located"); Conn. Gen. Stat. § 33-756(d) (3)-(4) (2012) (“[A] director of a corporation [...]. may consider [...]. the interests of the corporation's employees, customers, creditors and suppliers, [as well as] community and societal considerations including those of any community in which any office or other facility of the corporation is located."). See also Revlon, Inc. v. Macandrews \& Forbes Holdings, Inc., 506 A.2d 173, 182 (Del. 1986) ("A board may have regard for various constituencies in discharging its responsibilities, provided there are rationally related benefits accruing to the stockholders"); Unocal Corp. v. Mesa Petroleum Co., 493 A.2d 946, 955 (Del. 1985) ("[The] directors [must analyze] the nature of the takeover bid and its effect on the corporate enterprise. Examples of such concerns may include: [...] the impact on "constituencies" other than shareholders (i.e., creditors, customers, employees, and perhaps even the community generally) [...]"). 
derivative suit should take into account these "other" constituencies ${ }^{37}$. Even a close corporation in which the stockholders play most or all of these stakeholder roles does not amount to the sum of its investors. It possesses a separate legal identity, bears liability to the extent of its own assets, and holds its own set of rights.

In these respects, a corporation differs from a traditional partnership. Contrary to the former, the latter legally constitutes nothing but an aggregation of its members ${ }^{38}$. It has no legal personality, property, or entitlements of its own, as opposed to those of its partners ${ }^{39}$. As a result, a suit on behalf of such an association essentially corresponds to an action in the name of its various associates ${ }^{40}$.

Certainly, a traditional partnership does come across as a collectivity, despite lacking legal recognition as such. Somewhat like a corporation, it seems to possess not only an identity apart from that of its members but also its own rights. Not surprisingly, the law has progressed toward conceiving partnerships in these terms ${ }^{41}$.

${ }^{37}$ Since a plaintiff in a derivative suit stands in for the directors, she should inherit their authority or obligation to consider these stakeholders. See supra note 36 and accompanying text.

${ }^{38}$ See Grand Grove of United Ancient Order of Druids v. Garibaldi Grove 130 Cal. 116, 119, 62 P. 486 (1900) ("[Unincorporated associations are not] recognized by the law as persons. They are mere aggregates of individuals called for convenience, like partnerships, by a common name").

39 See id. ("[Such] associations cannot, therefore, acquire or hold property [...] All the property said to belong to it is in fact the property of its members and each man's share of it is his own private property").

${ }^{40}$ See id. ("For the same reason such associations cannot sue or be sued. In suits where they are apparently parties, the real parties are the members of the association, who - as in the case of partnerships - are sued by the company name").

${ }^{41}$ See Unif. P'ship Act $\S 6(1)$ (1914) ("A partnership is an association of two or more persons to carry on as co-owners a business for profit."), id., $\S 8(1)$ (“All property originally brought into the partnership stock or subsequently acquired by purchase or otherwise, on account of the partnership, is partnership property"); id., § 8(2) ("Unless the contrary intention appears, property acquired with partnership funds is partnership property.”); Unif. P'ship Act § 101(6) (1997) (“"Partnership' means an association of two or more persons to carry on as co-owners a business for profit [...]"), id., § 201(a) 
In any event, a corporation, like a modern partnership, constitutes an entity separate from the individuals that form and fund it. It amounts to a distinct collectivity, composed of investors and dressed in corporate form. Whether bare or attired as a corporation, this collective body differs from the aggregation of its constituents.

To be sure, class actions sometimes operate like suits on behalf of a collectivity, not an aggregation of individuals. They do so particularly under Federal Rule of Civil Procedure 23(b)(2), when "[...] the party opposing the class has acted or refused to act on grounds that apply generally to the class, so that final injunctive relief or corresponding declaratory relief is appropriate respecting the class as a whole" ${ }^{\prime 2}$. For example, a school desegregation suit ordinarily seeks to enforce the entitlements not of the individual students, but rather of the excluded racial or ethnic group ${ }^{43}$.

Undoubtedly, a shareholder class ordinarily lacks the cohesiveness and the permanence of a racial or ethnic class. Therefore, the former normally does not constitute a collectivity in the same sense as the latter. Moreover, even in a shareholder class action for equitable relief under Rule 23(b)(2), the stockholders do not usually litigate as a cohesive group, but instead as a sizeable number of individuals with separate and interrelated claims ${ }^{44}$.

Nonetheless, a 23(b)(2) shareholder class action could seek an injunction against corporate measures that injure stockholders as a group

("A partnership is an entity distinct from its partners"), id., $\S 203$ ("Property acquired by a partnership is property of the partnership and not of the partners individually").

${ }^{42}$ Fed. R. Civ. P. 23(b)(2).

${ }^{43}$ See Fed. R. Civ. P. 23 advisory committee's note (1966 Amendment) (Subdivision (b) (2)) ("Illustrative are various actions in the civil-rights field where a party is charged with discriminating unlawfully against a class, usually one whose members are incapable of specific enumeration.")

${ }^{44}$ See, e.g., In re Celera Corp. Shareholder Litigation, 59 A.3d 418, 433 (Del. 2012) (In a suit on behalf of a large number of stockholders, "certification under Rule 23(b)(2) is appropriate when the rights and interests of the class members are homogeneous. A Rule 23(b)(2) class may seek monetary damages in addition to declaratory or injunctive relief, so long as the claim for equitable relief predominants [sic]."). 
rather than individually. For instance, it might allege that the board arbitrarily revoked a long-established written commitment to distribute dividends regularly to all investors. Such a suit would resemble the previously cited controversy over racial discrimination in education in that it would concern a collectivity as the real party in interest. Class members could not point to an entitlement that they possessed, to an injury that they endured, or to a remedy that they could request, independent of and distinct from that of their peers.

In fact, these specific shareholder class actions operate collectively somewhat along the lines of derivative suits. They also involve a claim that pertains to stockholders as a group. Nonetheless, the real party in interest is the investor community in its naked state, so to speak, rather than in the garb of a corporation.

All the same, shareholder class actions typically proceed under Rules 23(b)(1) or 23(b)(3), not under Rule 23(b)(2) ${ }^{45}$. On the one hand, they may involve cases in which, as expressed in Rule 23(b)(1), "[...] prosecuting separate actions [...] would create a risk of: (A) [...]

${ }^{45}$ For purposes of this article, Lauren Kinell conducted a survey on Westlaw of United States District Court decisions certifying shareholder class actions for a twelve-month period starting on June 2, 2012. She found that certification always took place either under 23(b)(1) or 23(b)(3). See Erica P. John Fund, Inc. v. Halliburton Co., 718 F.3d 423, 427 (5th Cir. Apr. 30, 2013) (certifying a class of shareholders under Rule 23(b)(3)); Davis v. Cent. Vermont Pub. Serv. Corp., No. 5:11-CV-181, 2012 WL 4471226, at 6-7 (D. Vt. Sept. 27, 2012) (certifying class of shareholders under Rule 23(b)(1)); In re Winstar Commc'ns Sec. Litig., No. 01 CIV. 3014, 2013 WL 1700993, at*3 (S.D.N.Y. Apr. 17, 2013) (certifying a class of shareholders under Rule 23(b)(3)); In re Smith Barney Transfer Agent Litig., 290 F.R.D. 42, 45 (S.D.N.Y. Mar. 21, 2013) (certifying a class of shareholders under Rule 23(b)(3)); In re Merck \& Co., Inc. Sec., Derivative \& ERISA Litig., Nos. 05-1151 \& 05-2367, 2013 WL 396117, at*1 (D.N.J. Jan. 30, 2013) (certifying a class of shareholders under Rule 23(b)(3)); In re Smart Techs, Inc. S'holder Litig., No. 11 CIV. 7673 KBF, 2013 WL 139559, at*1 (S.D.N.Y. Jan. 11, 2013) (certifying a class of shareholders under Rule 23(b)(3)); Katz v. China Century Dragon Media, Inc., 287 F.R.D. 575, 583 (C.D. Cal. 2012) (certifying a class of shareholders under Rule 23(b)(3)); Vinh Nguyen v. Radient Pharmaceuticals Corp., 287 F.R.D. 563, 575 (C.D. Cal. 2012) (certifying a class of shareholders under Rule 23(b)(3)); In re Schering-Plough Corp./ ENHANCE Sec. Litig., No. 8-397, 2012 WL 4482032, at *7 (D.N.J. Sept. 25, 2012) (certifying a class of shareholders under Rule 23(b)(3)). 
incompatible standards of conduct for the party opposing the class; or (B) adjudications [...] that, as a practical matter, would [...] impair [the] ability [of other members] to protect their interests" 46 . On the other hand, shareholder class actions may address situations in which, as phrased in Rule 23(b)(3), “[...] questions of law or fact common to class members predominate over any questions affecting only individual members [...] and $[\ldots]$ a class action is superior to other available methods for fairly and efficiently adjudicating the controversy" ${ }^{\prime 4}$.

The Advisory Committee on the key 1966 Amendments to Rule 23 mentioned the possibility of processing "actions by shareholders to compel the declaration of a dividend[,] the proper recognition and handling of redemption or pre-emption rights, or the like" under Rule $23(\mathrm{~b})(1)(\mathrm{B})^{48}$. To be sure, it also cautioned that "[...] the matter has been much obscured by the insistence that each shareholder has an individual claim"49. Nonetheless, the Committee was presumably not denying "that each shareholder has an individual claim" 50 . It evidently thought that the "insistence" 51 on this point obfuscated the fact that these suits "should ordinarily be conducted as class actions," 52 inasmuch as stockholders litigating subsequently would, in the words of Rule 23(b)(1)(B), have "their ability to protect their interests" 53 impaired, "as a practical matter" 54 . Significantly, the Committee distinguished such "shareholders" actions $[\ldots]$ from derivative actions by shareholders dealt with in [...] Rule 23.1" ${ }^{55}$.

\footnotetext{
${ }^{46}$ Fed. R. Civ. P. 23(b)(1).

${ }^{47}$ Fed. R. Civ. P. 23(b)(3).

${ }^{48}$ Fed. R. Civ. P. 23 advisory committee's note (1966 Amendment) (discussing Subdivision (b)(1); Clause (B)).

${ }^{49}$ Id.

${ }^{50} \mathrm{Id}$.

${ }^{51} I d$.

${ }^{52} \mathrm{Id}$.

${ }^{53}$ Fed. R. Civ. P. 23(b)(1)(B).

${ }^{54} I d$.

${ }^{55}$ Fed. R. Civ. P. 23 advisory committee's note (1966 Amendment) (Subdivision (b)(1); Clause (B)).
} 
Beyond the scenarios discussed to in the previous paragraph, shareholder class actions mostly call for certification under the catchall Rule 23(b)(3) ${ }^{56}$. After all, they aggregate a multiplicity of discrete claims. The judiciary could adjudicate the case satisfactorily through "separate actions;" 57 yet it could do so more effectively through a single class action.

In sum, plaintiffs in these and in most other shareholder class actions do not engage in collective litigation in the same manner as their counterparts in derivative suits. The latter seek to vindicate the rights of a true collectivity, to wit, the corporation. The former, for their part, purport to enforce the entitlements of many individual investors.

Indeed, derivative suits relate to shareholder class actions, in this respect, as citizen suits do to ordinary class actions. In derivative and citizen suits, the real party in interest is a collectivity: the corporation and society as a whole, respectively. In shareholder and ordinary class actions, the real parties in interest are actually the affected individuals.

As an illustration, a citizen may litigate on behalf of the community at large against a pharmaceutical company that is allegedly contaminating the air and, hence, the communal quality of life. She may alternatively sue the same defendant in her own name and that of the many others whose property has similarly lost value due to the pollution. The first action would recall a derivative suit in that it concerns the indivisible entitlements of a collectivity. The second suit, however, would resemble a shareholder class action in that it turns on the discrete rights of an outsize number of people.

Of course, societies and corporations ultimately consist of their citizens and stockholders, respectively. Moreover, one could assess the

${ }^{56}$ See Joseph A. Grundfest \& Michael A. Perino, The Pentium Papers: A Case Study of Collective Institutional Investor Activism in Litigation, 38 Ariz. L. Rev. 559, 564 n. 22 (1996) ("Shareholder class actions are most often certified under Rule 23(b)(3) [...]"). In Lauren Kinell's survey, conducted for the benefit of this Article, class certification took place under Rule 23(b)(3) in eight out of nine United States District Court cases during a twelve-month period starting on June 2, 2012. See supra note 45.

${ }^{57}$ Fed. R. Civ. P. 23(b)(3)(A). 
value of any asset or any entitlement of either of these collectivities, divide it by the number of constituents, and thus translate any collective claim on it into a multiplicity of individual claims. Nonetheless, such a complex operation would underscore, rather than cast doubt upon, the significance of the distinction between the collective and the individual. At the end of the day, it would lend some support to the notions that people constitute unprecedented and only artificially translatable grouprights when they build a nation and that individual investors do the same when they form a corporate entity.

\subsection{The Nature of the Representation}

The second formal point of similarity between derivative suits and shareholder class actions, to wit, their representative character, also exposes itself as a point of dissimilarity upon deeper inspection. In particular, these two procedural mechanisms differ in the kind of representation they entail. In derivative suits, the plaintiffs represent a party other than themselves and to whom they relate as investors ${ }^{58}$. In shareholder class actions, they represent themselves along with other, similarly positioned stockholders ${ }^{59}$.

Federal Rule of Civil Procedure 23.1 might generate some confusion on this front with the following assertion: "The derivative action may not be maintained if it appears that the plaintiff does not fairly and adequately represent the interests of shareholders or members who are similarly situated in enforcing the right of the corporation or association" 60 . This provision appears to insinuate that the complainant, in derivative suits as well as in class actions, acts as the representative of other, equally entitled stockholders.

The history of derivative suits may help explain this requirement of adequate representation of similarly positioned investors.

\footnotetext{
${ }^{58}$ See supra note 1 and accompanying text.

${ }^{59}$ See supra note 3 and accompanying text.

${ }^{60}$ Fed. R. Civ. P. 23.1(a).
} 
Historically, the derivative suit was conceived of as a double suit, or two suits in one: "The plaintiff (1) brought a suit in equity against the corporation seeking an order compelling it (2) to bring a suit for damages or other relief against some third person who had caused legal injury to the corporation ${ }^{61}$ ".

In the first suit, the plaintiff represented herself and other stockholders in an attempt to compel the corporation to take action. She therefore had to play her representative role adequately with respect to her fellow investors. In the second suit, the actual derivative action, the complainant undertook the representation of the corporate entity and assumed no duties vis-à-vis other stockholders.

Presently, the two actions unfold together, as one. According to the Delaware Supreme Court, a derivative suit consists of two phases: "the stockholder's suit to compel the corporation to sue and the corporation's suit" 62 . In other words, "[t]he nature of the action is two-fold. First, it is the equivalent of a suit by the shareholders to compel the corporation to sue. Second, it is a suit by the corporation, asserted by the shareholders on its behalf, against those liable to it" ${ }^{\prime \prime}$. Therefore, the plaintiff represents, on the one hand, all of her fellow shareholders in demanding a suit and, on the other hand, the corporation in vindicating the encroached upon corporate entitlements.

In the first stage, however, the complainant acts on behalf of stockholders as a group, not of individual investors. She plays a role analogous to that of someone who lodges a 23(b)(2) class action for an injunction against segregation in elementary schools. In both scenarios, the collectivity holds the right, not its members individually. The requirement in derivative suits that the plaintiff "fairly and adequately

\footnotetext{
${ }^{61}$ Robert Charles Clark, Corporate Law 639-40 (1986).

${ }^{62}$ Zapata Corp. v. Maldonado, 430 A.2d 779, 784 (Del. 1981).

${ }_{63}$ Aronson v. Lewis, 473 A.2d 805, 811 (Del. 1984), overruled on other grounds by Brehm v. Eisner, 746 A.2d 244 (Del. 2000). See also Harff v. Kerkorian, 324 A.2d 215, 218 (Del. Ch.1974) ("The nature of the derivative suit is twofold: first, it is the equivalent of a suit by the stockholders to compel the corporation to sue; and second, it is a suit by the corporation, asserted by the stockholders in its behalf, against those liable to it.").
} 
represent the interests of shareholders [...] who are similarly situated"64 may blur but does not actually alter this fact. The Federal Rule of Civil Procedure on class actions speaks more clearly of fair and adequate representation of "the interests of the class" 65 .

In fact, the first phase amounts to a genuinely collective class action, like many of those processed under Rule 23(b)(2). In other words, the plaintiffs represent themselves and other stockholders, not as an aggregation of individuals, but instead as a cohesive community. Consequently, they assert a claim that belongs to the group as a whole and that allows no apportionment among the various investors.

Once again, citizen suits and ordinary class actions help illustrate the divergence at issue in this subsection. The former, like derivative suits, entail representation of a separate entity, which counts the plaintiff as one of its many constituents. The latter, like shareholder class actions, involve a complainant who represents herself in addition to a multiplicity of similarly positioned individual class-members.

Accordingly, the plaintiff in the environmental citizen suit evoked earlier acts in representation of the society in its entirety. She does not really represent similarly situated fellow citizens or, rather, represents them only as a collectivity. In contrast, the complainant in the parallel class action does litigate on behalf of the landowners whose property, like hers, lost value due to the pollution.

\subsection{Instrumental and Reflexive Procedural Aims}

With respect to the third point of comparison, namely the underlying aim, derivative suits differ from shareholder class actions in that they instrumentally pursue, beyond the settlement of a dispute between stockholders and directors, the structural reform of the corporation ${ }^{66}$.

${ }^{64}$ Fed. R. Civ. P. 23.1.

${ }^{65}$ Fed. R. Civ. P. 23(a)(4).

${ }^{66}$ See, e.g., Jessica Erickson, Corporate Governance in the Courtroom: An Empirical Analysis, 51 Wm. \& Mary L. Rev. 1749, 1754 (2010) ((explaining that derivative suits more often lead to "reform [in] corporate governance practices" through settlement rather than to "meaningful financial benefit" to the corporation). 
In particular, they seek to alter the power structure in order to grant investors more of a say in corporate decision making, at least with respect to the derivatively asserted claims ${ }^{67}$. More generally, the introduction of derivative litigation constitutes a considerable shift of control from the directors back to the stockholders.

In this sense, derivative suits tend not only to distance themselves from shareholder class actions but also to come closer to public law litigation ${ }^{68}$. For instance, they focus, along the lines of the latter and in contrast to the former, on creating a completely new state of affairs rather than on reestablishing the status quo ante ${ }^{69}$. Upon a favorable judgment, stockholders as a collectivity end up making the contested decision to sue and augmenting their influence within the corporation.

Furthermore, derivative suits, like public law litigation and as opposed to shareholder class actions, aim at structurally injunctive, as well as compensatory, relief ${ }^{70}$. They purport to compel the corporation

${ }^{67}$ See Bryant G. Garth et al., Empirical Research and the Shareholder Derivative Suit: Toward a Better-Informed Debate, 48 Law \& Contemp. Probs. 137, 158 (1985) ("[In derivative suits, the] real question is about controlling economic power. [Therefore], the derivative suit represents a complex social institution that helps regulate power conflicts"). See also Cohen v. Beneficial Indus. Loan Corp., 337 U.S. 541, 548 (1949) ("This remedy born of stockholder helplessness was long the chief regulator of corporate management and has afforded no small incentive to avoid at least grosser forms of betrayal of stockholders' interests. It is argued, and not without reason, that without it there would be little practical check on such abuses.").

${ }^{68}$ See generally Abram Chayes, The Role of the Judge in Public Law Litigation, 89 Harv. L. Rev. 1281 (1976) (explaining the necessity of judicial involvement in public law litigation in an increasingly regulated society); Owen M. Fiss, The Political Theory of the Class Action, 53 Wash. \& Lee L. Rev. 21 (1996) (explaining that civil class actions can serve a public as well as a private purpose); Owen M. Fiss, The Social and Political Foundations of Adjudication, 6 L. \& Hum. Behav. 121 (1982) (discussing the role of adjudication in enforcing constitutional values).

${ }^{69}$ See Erickson, supra note 66, at 1754.

${ }^{70}$ See, e.g., Emerald Partners v. Berlin, 787 A.2d 85, 88 (Del. 2001) (“[Plaintiff] filed . .. [the] action . . . to enjoin the consummation of a merger"); MCA, Inc. v. Matsushita Elec. Indus. Co., Ltd., 785 A.2d 625, 629 (Del. 2001) (“[P]laintiffs . . f filed an amended complaint seeking preliminary injunctive relief against consummation of the Tender Offer"). See also Stephen P. Ferris et al., Derivative Lawsuits as a Corporate Governance 
to assert the claim at stake and not simply to secure the unclaimed reparation $^{71}$. As previously suggested, shareholder class actions may indeed seek an equitable remedy; yet they normally do not call for significant interference in the board's exercise of authority.

Finally, judges usually become more profoundly engaged in derivative and public law suits than in shareholder class actions. Indeed, they must go beyond protecting the interests of absent class members in order to make sure that they do justice to the stockholders as a group and to the corporation itself. In a derivative suit, the ultimate judgment must strike a delicate balance among the interests of investors, directors, and stakeholders ${ }^{72}$. In an ordinary shareholder-class-action, however, the judiciary must simply assess whether the corporation has encroached upon the stockholders' entitlements and how best to distribute the compensation in case of liability ${ }^{73}$.

Mechanism: Empirical Evidence on Board Changes Surrounding Filings, 42 J. Fin. \& Quantitative Analysis 143, 146 (2007) ("The derivative lawsuit might serve its purpose by publicizing the firm's agency problems, thus leading the firm to institute governance changes not directly captured in the litigation process.").

${ }^{71}$ See Aronson v. Lewis, 473 A.2d 805, 811 (Del. 1984), overruled on other grounds by Brehm v. Eisner, 746 A.2d 244 (Del. 2000); Zapata Corp. v. Maldonado, 430 A.2d 779, 784 (Del. 1981).

72 See Zapata, 430 A.2d at 788 (quoting Maldonado v. Flynn, 485 F. Supp. 274, 285 (1980)) (" $[\mathrm{W}] \mathrm{e}$ recognize that 'the final substantive judgment whether a particular [derivative] lawsuit should be maintained requires a balance of many factors - ethical, commercial, promotional, public relations, employee relations, fiscal as well as legal"').

${ }^{73}$ Rule 23 of the Federal Rules of Civil Procedure "provides that all class actions maintained to the end as such will result in judgments including those whom the court finds to be members of the class ... and refers to the measures which can be taken to assure the fair conduct of these actions." Fed. R. Civ. P. 23 advisory committee's note (1966 Amendment). The tribunal must adjudicate on "the claims ... of the representative parties", as well as on "the claims [...] of the class." Fed. R. Civ. P. 23(a)(3). In addition, it must assure, also in the distribution any damages awarded, a fair and adequate protection of "the interests of the class." Fed. R. Civ. P. 23(a)(4) \& (g)(1)(B). See, e.g., Eisen et al. v. Carlisle \& Jacquelin, 417 U.S. 156, 165-166 (1974) ("[In] a class action on behalf of . . . odd-lot traders on the New York Stock Exchange, ... the [trial] court dealt with problems of the computation of damages, the mechanics of administering [the] suit as a class action, and the distribution of any eventual recovery."). 
Of course, derivative suits and shareholder class actions equally entail complex litigation. Therefore, they both demand considerable judicial engagement, which the law defines in almost identical terms. On the one hand, the "[...] court has inherent power to provide for the conduct of the proceedings in a derivative action, including the power to determine the course of the proceedings and require that any appropriate notice be given to shareholders or members"74. On the other hand, in "[...] conducting [a class] action, the court may issue orders that (A) determine the course of proceedings or prescribe measures to prevent undue repetition or complication in presenting evidence or argument [or that] (B) require - to protect class members and fairly conduct the action - giving appropriate notice to some or all class members [... $]^{\prime 75}$.

Nonetheless, derivative suits differ from shareholder class actions in that they impose on the tribunal a qualitative, rather than a quantitative, challenge. In particular, they call on the judiciary to adjudicate a qualitatively extraordinary claim, not simply to entertain a sizeable quantity of standard claims at once. The judge must rule, extraordinarily, on the appropriateness of allowing the complainants to displace the board of directors, as well as, rather ordinarily, on whether the corporation should prevail on the merits. In each one of her determinations along the way, she must draw on the entire procedural apparatus at her disposal in order to consider the perspectives of the stockholder plaintiffs, the managers, the experts, and the stakeholders and ultimately to promote the company's well-being. In fact, the directors may at any point and repeatedly prior to trial present an independent-committee determination that the litigation no longer serves the interests of the corporation and move for dismissal ${ }^{76}$.

This entire discussion suggests that the two procedural mechanisms differ in their reflexive aim, as well as in their instrumental objective.

\footnotetext{
${ }^{74}$ Fed. R. Civ. P. 23.1 advisory committee's note (1966 Amendment).

${ }^{75}$ Fed. R. Civ. P. 23 (d)(1)(A, B).

${ }^{76}$ Zapata Corp., 430 A.2d at 788 ("After an objective and thorough investigation of a derivative suit, an independent committee may cause its corporation to file a pretrial motion to dismiss in the Court of Chancery. The basis of the motion is the best interests of the corporation, as determined by the committee. The motion should include a thorough written record of the investigation and its findings and recommendations").
} 
Derivative suits, in contradistinction to shareholder class actions, aspire to enable stockholders, not as individuals but as a collective unit, to relate to management throughout the proceedings and beyond in fair and equitable terms. Once again, the configuration of this relationship in court will bear upon how these and other groups interact with each other after the litigation

\subsection{Adequacy of Representation}

Regarding the fourth and last comparative angle, the problem of adequacy of representation manifests itself differently in the context of these two procedural devices. In shareholder class actions, the court must safeguard the due process rights of absent class members. In derivative suits, it must not only protect the entitlements of the represented entity but also exert itself to preserve the autonomy of that collectivity.

As previously noted, the corporation, rather than any of the stockholders, constitutes the real party in interest in derivative suits. It participates in the proceedings as a defendant and, therefore, does not ordinarily risk a violation of its procedural entitlements or a systematic disregard of its point of view ${ }^{77}$. Nonetheless, this type of litigation entails the displacement and, potentially, the sterilization of the board of directors. Hence, it may undermine the investors' collective effort to govern the corporation through that representative body.

Once again, citizen suits and ordinary class actions present an analogous contrast. The former, contrary to the latter, do not call for the protection of the rights of the members of the collectivity. Rather, they demand the prevention of any destabilization of the political branches of government.

In the example evoked earlier, the plaintiff does not potentially endanger the substantive entitlements of any of her fellow citizens by asserting the community's environmental claims against the

77 See, e.g., Cannon v. U. S. Acoustics Corp., 398 F. Supp. 209, 213 (E.D. Ill. 1975) ("A derivative suit is, in legal effect, a suit brought by the corporation, but conducted by the shareholders. The corporation [is] formally aligned as a defendant for historical reasons.”); Sohland v. Baker, 141 A. 277, 281 (Del. 1927) (“[A] stockholder may sue in his own name for the purpose of enforcing corporate rights, though the corporation in question is nominally a party defendant."). 
pharmaceutical company. Even so, she may hamper the authorities' engagement on the same front. For instance, the state may have already initiated litigation on the same matter or may have decided to abstain from doing so in light of the defendant's voluntary undertakings to solve the problem.

Similarly, a stockholder does not impinge upon the rights of her peers when she pursues a claim against one of the corporation's debtors. Nevertheless, she may frustrate corporate endeavors to address the issue. The directorate may have already filed a prior, identical complaint or may have refrained from such a course of action in the expectation of obtaining some other benefit from the alleged violator.

All too often, however, the judiciary has approached these issues too narrowly in corporate controversies. It has assumed that stockholders, as a group, should exercise their self-determination exclusively through the board ${ }^{78}$. As a result, the case law authorizes derivative suits only when the directors have hopelessly compromised themselves ${ }^{79}$.

Ideally, the law should shift from a representative to a participatory conception of shareholder democracy. It should appreciate, accordingly,

78 See Levine v. Smith, 591 A.2d 194, 200 (Del. 1991) ("The directors of a corporation and not its shareholders manage the business and affairs of the corporation [...], and accordingly, the directors are responsible for deciding whether to engage in derivative litigation."); Aronson v. Lewis, 473 A.2d 805, 812 (Del. 1984), overruled on other grounds by Brehm v. Eisner, 746 A.2d 244 (Del. 2000) ("The business judgment rule is an acknowledgment of [...]. managerial prerogatives [...]. It is a presumption that in making a business decision the directors of a corporation acted on an informed basis, in good faith and in the honest belief that the action taken was in the best interests of the company [...]. Absent an abuse of discretion, that judgment will be respected by the courts. The burden is on the party challenging the decision to establish facts rebutting the presumption"); Miller v. American Tel. \& Tel. Co., 507 F.2d 759, 762 (9th Cir. 1974) ("The sound business judgment rule [...]. expresses the unanimous decision of American courts to eschew intervention in corporate decision-making if the judgment of directors and officers in uninfluenced by personal considerations and is exercised in good faith"). See generally James D. Cox, Searching for the Corporation's Voice in Derivative Suit Litigation: A Critique of Zapata and the ALI Project, 1982 Duke L.J. 959, 972 ("[C] ommercial considerations [...]. justify the overwhelming deference courts accord director decisions in normal commercial transactions").

79 See supra notes 14-17, 78 and accompanying text. 
that investors participate in corporate decision making not only through their vote but also through other means, such as shareholder inspections, shareholder proposals, and derivative suits. When suing derivatively, plaintiffs should not have to allege with particularity in the complaint a conflict of interest or wrongful refusal. Moreover, they should have the right to minimal process when they initially ask the corporation to assert the contested claim. In other words, the law should entitle the stockholders who are pushing for litigation to a corporate written response and, if they make a facially meritorious case on paper, to a face-to-face meeting with corporate officials.

In all likelihood, however, tribunals will continue to reject this approach out of a somewhat speculative concern with the prospect of an increase in the number of filings. They will probably persist in requiring stockholders to make a demand on the board, ${ }^{80}$ in construing such a request as a concession of independence, ${ }^{81}$ in allowing the corporation to refuse without any kind of hearing, ${ }^{82}$ and in compelling plaintiffs to show the wrongness of such refusal during the pleadings. ${ }^{83}$ Hence, derivative suits will most certainly not develop, in the near future, their full potential as a vehicle for the empowerment of stockholders as a collectivity.

Of course, derivative litigation may thwart the directorate's work. "By its very nature, the derivative action impinges on the managerial freedom of directors" $" 84$. As a result, it may hinder the investors' exercise of self-determination through their regular representatives.

\footnotetext{
${ }^{80}$ See supra note 15 and accompanying text.

${ }^{81}$ See Levine, 591 A.2d at 212 ("A shareholder plaintiff, by making demand upon a board before filing suit . . . tacitly concedes lack of self-interest and independence of a majority of the Board").

${ }^{82}$ See id. at 214 ("While a board of directors has a duty to act on an informed basis in responding to a demand ..., there is obviously no prescribed procedure that a board must follow").

${ }^{83}$ See Beam v. Stewart, 845 A.2d 1040, 1048-1049 (Del. 2008) ("The [...] directors are entitled to a presumption that they were faithful to their fiduciary duties. In the context of presuit demand, the burden is upon the plaintiff in a derivative action to overcome that presumption.").

${ }^{84}$ Aronson v. Lewis, 473 A.2d 805, 811 (Del. 1984), overruled on other grounds by Brehm v. Eisner, 746 A.2d 244 (Del. 2000).
} 
Naturally, the judiciary must keep such danger in mind and at bay. Consequently, it must painstakingly probe into whether the litigation might undercut the autonomy of stockholders as a collectivity. At the end of the day, the recommended approach may or may not increase the number of suits, yet it will center on what matters, namely, the preservation of shareholder self-determination, rather than on intrinsically irrelevant issues, such as whether the complaint particularizes self-dealing by the directors.

All the same, courts should acknowledge that stockholders embark upon an alternative and potentially constructive kind of democratic engagement when they sue derivatively. In fact, derivative suits constitute, in a formulation by Robert Clark repeatedly quoted by the Delaware Supreme Court, "one of the most interesting and ingenious of accountability mechanisms for large formal organizations" ${ }^{\prime 85}$. Hence, judges should reasonably accommodate derivative litigation instead of limiting it to clear cases of directorial partiality.

Part V will revisit these matters. In the end, it will propose that derivative suits follow the lead of citizen suits and entitle the plaintiffs to proceed even when the collectivity's legitimate representatives show disinterestedness on the issue at hand. Under this proposition, the directors would hold the right to: (1) receive notice of the complaint and of any settlement, (2) stake the claim themselves, and (3) stop the litigation by demonstrating that it would either harm the corporation or jeopardize the collective autonomy of the investors.

\subsection{Distinguishing Derivative and Direct Suits}

The approach discussed in Part III facilitates understanding derivative suits and shareholder class actions. The former essentially entail the vindication of an authentically collective right. The latter involve, basically, the enforcement of an aggregation of individual entitlements.

${ }^{85}$ Clark, supra note 61, at 639 (cited in Ams. Mining Corp. v. Theriault, 51 A.3d 1213, 1264 (Del. 2012); Tooley v Donaldson, Lufkin \& Jenrette, Inc., 845 A2d 1031, 1036 (Del. 2004); Kramer v. Western Pacific Industries, Inc., 546 A.2d 348, 351 (1987)). 
At the same time, this vantage point would help the judiciary to distinguish the two procedures. When tracing this distinction in a concrete controversy, courts would focus on the nature of the right that the plaintiff is seeking to vindicate. They would ask whether such entitlement is collective or individual. Thereafter, the analysis would proceed to consider who suffered the injury and who would benefit from the redress.

To be sure, most of these controversies do not present themselves as shareholder class actions. The complainant usually purports to represent herself only, not a sizeable number of stockholders ${ }^{86}$. The defendants, for their part, normally strive to categorize the suit as derivative in order to saddle their adversary with onerous pleading prerequisites ${ }^{87}$.

These more common disputes present an even starker contrast between the collective and the individual. After all, the tribunal faces a dichotomy between derivative and individual suits, ${ }^{88}$ not between derivative suits and shareholder class actions. It does not have to interpret an aggregative class action as ultimately individual.

At any rate, the Delaware Supreme Court has striven to differentiate derivative and direct suits as clearly and as simply as possible ${ }^{89}$. In Tooley

\footnotetext{
${ }^{86}$ Compare Feldman v. Cutaia, 951 A.2d 727, 729 (Del. 2008) (Plaintiff "contends that his claim [...] was an individual one and not derivative in nature") with Tooley, 845 A2d at 1033 ("Plaintiff-stockholders brought a purported class action in the Court of Chancery"). ${ }^{87}$ See, e.g., Feldman, 951 A.2d at 730 ("[T]he defendants moved to dismiss [plaintiff's] complaint [...]. The motion to dismiss asserted that [plaintiff] had lost standing to pursue derivative claims."); Tooley, 845 A.2d at 1033 (“The Court of Chancery granted the defendants' motion to dismiss on the sole ground that the claims were [...]. claims of the corporation being asserted derivatively. They were, thus, held not to be direct").

${ }^{88}$ See Ams. Mining Corp., 51 A.3d at 1264 ("[A] stockholder who is directly injured retains the right to bring an individual action for those injuries affecting his or her legal rights as a stockholder. Such an individual injury is distinct from an injury to the corporation alone."); Tooley, 845 A.2d at 1036 ("A stockholder who is directly injured [has] the right to bring an individual action for injuries affecting his or her legal rights as a stockholder. Such a claim is distinct from an injury caused to the corporation alone. In such individual suits, the recovery or other relief flows directly to the stockholders").

${ }^{89}$ See Tooley, 845 A2d at 1036 ("Therefore, it is necessary that a standard to distinguish such actions be clear, simple and consistently articulated and applied by our courts").
} 
$v$ Donaldson, Lufkin \& Jenrette, Inc., it actually confronted "a purported class action" 90 and went on to characterize "some concepts in [its] prior jurisprudence" as "not helpful and [...] erroneous" ". The justices thereupon "set forth $[\ldots]$ the law to be applied $[\ldots]$ in determining whether a stockholder's claim is derivative or direct"92. "That issue," they proclaimed, "must turn solely on the following questions: (1) who suffered the alleged harm (the corporation or the suing stockholders, individually); and (2) who would receive the benefit of any recovery or other remedy (the corporation or the stockholders, individually)"993?

The tribunal further elaborated on its test:

That is, a court should look to the nature of the wrong and to whom the relief should go. The stockholder's claimed direct injury must be independent of any alleged injury to the corporation. The stockholder must demonstrate that the duty breached was owed to the stockholder and that he or she can prevail without showing an injury to the corporation ${ }^{94}$.

Consequently, a suit qualifies as derivative, as opposed to direct, if the corporation, rather than the stockholders, not only has endured the damage but also would stand to gain from the reparation. In a direct action, plaintiffs must show harm to them independent of any harm to the corporate entity.

The Delaware Supreme Court has repeatedly endorsed this 2004 "landmark decision." 95 In Americas Mining Corp. v. Theriault, the tribunal accordingly distinguished a derivative suit from "a class action

\footnotetext{
${ }^{90} I d$. at 1033 .

${ }^{91} I d$.

${ }^{92} I d$.

${ }^{93} \mathrm{Id}$.

${ }^{94} \mathrm{Id}$. at 1039.

${ }^{95}$ Feldman v. Cutaia, 951 A.2d 727, 729 (Del. 2008); see, also, Ams. Mining Corp. v. Theriault, 51 A.3d 1213, 1264-1265 (Del. 2012); Brooks-McCollum v. Emerald Ridge Bd. of Dirs., No. 104, 2011, slip op. at 5 (Del. Oct. 5, 2011).
} 
[on behalf of] minority stockholders only"96. "Because a derivative suit is brought on behalf of the corporation," the justices underscored, "any recovery must go to the corporation" 97 .

The Tooley standard zeroes in on two crucial elements for the classification of a particular action as derivative or direct: the locus of the injury and the beneficiary of the remedy ${ }^{98}$. It should have added, and actually started with, the key factor: the kind of right invoked. In this respect, the inquiry boils down to whether the claimant is seeking to vindicate collective or individual entitlements.

In fact, Tooley does allude to this issue. It notes, in its elucidation, that the complainant in a direct action "must demonstrate that the duty breached was owed to the stockholder" 99 . Of course, a duty ordinarily correlates with a right ${ }^{100}$. Therefore, the demonstration that the defendants encroached upon an individual duty fundamentally amounts to a showing that they infringed upon an individual entitlement.

Maybe the Delaware Supreme Court did not proceed to include the nature of the right in the test because it believed that doing so would entail circular reasoning. Specifically, it may have thought that it was trying to define the entitlement at hand. Had the justices faced such a task, they indeed would have had every logical reason to refuse to list the entitlement's definition as one of the considerations.

\footnotetext{
${ }^{96}$ Ams. Mining Corp., 51 A.3d at 1265.

${ }^{97} \mathrm{Id}$. at 1264.

${ }^{98}$ See Tooley, 845 A.2d at 1033.

${ }^{99} \mathrm{Id}$. at 1039.
}

${ }^{100}$ See generally Joseph Raz, The Nature of Rights (Ch. 7), The Morality of Freedom 165192,166 (1986) ("'X has a right' if and only if X can have rights, and, other things being equal, an aspect of X's well-being (his interest) is a sufficient reason for holding some other person(s) to be under a duty"). Cf. Martha Nussbaum, Capabilities and Human Rights, 66 Fordham L. Rev. 273-300, 274 (1997) ("Still another unresolved question is whether rights -thought of as justified entitlements - are correlated with duties. If $A$ has a right to $S$, then it would appear there must be someone who has a duty to provide $S$ to $A$. But it is not always clear who has these duties - especially when we think of rights in the international context. Again, it is also unclear whether all duties are correlated with rights"). 
Nonetheless, the tribunal confronted the challenge of defining the claim, not the right. Thereupon, it should have perceived the former concept as broader than and as inclusive of the latter. A claim commonly encompasses an alleged entitlement, injury, and remedy. The claimant must point to the harm suffered and the relief demanded, in addition to the infringed-upon right ${ }^{101}$. She may not claim anything if she fails to identify the damage endured and the reasonably requested reparation, even if she, in fact, holds the entitlement invoked.

Ordinary language supports, to some extent, a divide between the terms "claim" and "right." Parties normally assert or stake a claim ${ }^{102}$. In contrast, they seek to vindicate or enforce a right ${ }^{103}$. This usage suggests that the underlying acts differ from each other.

In sum, judges may consistently categorize a claim as derivative or direct based on whether the entitlement, the injury, and the remedy pertain collectively to the corporation or individually to the stockholders. Of course, this approach would not render the analysis any easier. Nonetheless, it would lead the judiciary to focus on all of the relevant factors and to deal with hard cases more sensibly.

The facts in Feldman v. Cutaia ${ }^{104}$ help illustrate the point. Feldman directly challenged the validity of certain stock options, which two managing directors and the general counsel of Telx had received in 2004 and exercised upon the corporation's merger into GI Partners in $2006^{105}$.

${ }^{101}$ Under the Federal Rules of Civil Procedure a "statement of the claim" must include a "showing that the pleader is entitled to relief" and "a demand for the relief sought." Fed. R. Civ. P. 8(a). The entitlement to relief rides on the existence and the violation of a right. ${ }^{102}$ See Webster's Third New International Dictionary of the English Language Unabridged 414 (3d ed. 2002) (defining "claim" as "a calling on another for something due or supposed to be due."). But cf. id. (defining "claim" as "a privilege to something: right ... specifically: a title to a debt, privilege, or other thing in the possession of another"); see also id. at 131 (defining "assert" as "to demonstrate the existence of").

103 See id. at 1955 (defining "right" as "something to which one has a just claim" and as "something that one may properly claim as due"); see also id. at 2553 (defining "vindicate" as "to protect from attack or encroachment: preserve, defend").

104951 A.2d 727 (Del. 2008).

${ }^{105} \mathrm{Id}$. at $729-730$. 
He evidently contended that the compensation plan took full effect in 2006 and that, at the time, it only could have injured the investors and called for indemnification in favor of them, inasmuch as Telx had ceased to exist ${ }^{106}$.

Under Tooley, Feldman should have prevailed. On the one hand, he had shown that the contested measure would exclusively harm the individual stockholders, if anybody ${ }^{107}$. On the other hand, he had demonstrated that any redress would have to go to them ${ }^{108}$.

The Delaware Supreme Court merely affirmed the Court of Chancery's ruling "that the alleged harm" in 2006 was "the same as the Company would have suffered [in 2004] from the invalidity of the Challenged Stock Options"109. Accordingly, if the first injury readily qualified as derivative, in light of Telx's full existence then, so must have the second, fundamentally identical injury. "In order to state a direct claim", the justices insisted, "the plaintiff [would have had to endure] some individualized harm not suffered by all of the stockholders at large" $" 110$.

This argument, at the very least, begs the question: If the board had an obligation to revoke the invalid stock options prior to approving the 2006 merger, would a violation not have inflicted damage upon and demanded a remedy for the investors? If so, the corresponding claim would have qualified as direct under Tooley.

Certainly, the trial judge might have found that the directors actually had no such duty, that no infringement or harm had taken place, or that the stockholders deserved no reparation. He might have even concluded that Feldman was simply rehashing, in the context of the 2006 merger approval, a prior contention about the 2004 stock options plan. These

\footnotetext{
106 The Delaware Supreme Court reports that Feldman alleged "that the defendants breached their fiduciary duties by not reconsidering the validity of the Challenged Stock Options before approving the Merger agreement." Id. at 730.

${ }^{107} I d$. at 728-30.

${ }^{108} I d$.

${ }^{109} I d$. at 730 .

${ }^{110} \mathrm{Id}$. at 733 .
} 
findings would have undermined the claim on the merits, yet they would not have transformed it from direct into derivative.

Moreover, a hypothetical controversy in which the directors granted the stock options as the last step in a previously endorsed merger would not essentially differ from the actual dispute. Nonetheless, it would render the Delaware Supreme Court's reasons completely inoperative. In particular, the justices would have to concede that their jurisprudence had led them to a dead end.

Consequently, tribunals should construe a claim like that in Feldman as derivative because it rests on a genuinely collective entitlement held by the corporation and by the stockholders as a whole. Whether this collectivity subsists after the dissolution of the corporation, at least for purposes of litigation, bears on the enforceability, but not on the nature of the right. In general, the disappearance of the real party in interest does not render her representative in court the holder of her entitlements, even though it may forestall any vindication thereof.

Under the extraordinary circumstances of Feldman, (1) the type of right invoked runs counter to and ultimately trumps the other criteria, viz., (2) the locus of the injury, and (3) the beneficiary of the relief. Otherwise, these three parameters normally point in the same direction. In any event, the judiciary may rely on the second and third parameters when in doubt with respect to the first one.

Of course, if the case law were to follow the suggestion submitted at the end of Part III and shift away from the burdensome pleading requirements imposed on derivative suits, it would reduce the significance of this entire distinction. Courts would tend to go into the merits straightaway. They would categorize the action as derivative or direct mostly in order to decide how to allocate the reparation.

As conceded earlier, the judiciary will probably keep compelling plaintiffs to make much of their case already in the complaint ${ }^{111}$. In all likelihood, it will also continue insisting that they "maintain

${ }^{111}$ See supra notes 80-83 and accompanying text. 
stockholder status in the corporate defendant throughout the litigation"112. Nonetheless, judges might be more open to the proposed standard for distinguishing derivative from direct suits because it would not, in any way, lower the bar for investors purporting to sue derivatively.

\subsection{Conceptualizing Collective Rights}

At the end of the day, grasping the difference between derivative suits and shareholder class actions sheds light on what collective rights are all about. Most fundamentally, one perceives that a genuinely collective right differs from an aggregation of discrete entitlements. A collective right belongs to the group, not to the individual members.

Accordingly, a derivative suit involves the entitlements of the corporation or of the collectivity of stockholders, not those of individual investors, who hold only an indirect interest ${ }^{113}$. In contrast, a shareholder class action turns on the individual rights of the stockholders. It combines, for purposes of procedural efficacy, a multiplicity of such entitlements, yet it does not thereby become an authentically collective procedure.

Of course, the temptation to reduce a collective right to a multiplicity of individual entitlements stems, in part, from the desire to avoid reifying the collectivity. A corporation or a group of stockholders does not exist in and of itself. Whoever attributes rights to such an entity seems to be treating it, implicitly and contradictorily, as existent.

However, the statement that derivative suits affect the entitlements of the corporation or of the collectivity of investors does not imply the existence of either in any paradoxical sense. It simply entails that the corporation exists as a legal entity and, as such, holds rights that the stockholders may vindicate derivatively. Such a construct of law can boast no other kind of existence.

${ }^{112}$ Feldman, 951 A.2d at 731 (citing Lewis v. Anderson, 477 A.2d 1040, 1046 (Del. 1984)).

${ }^{113}$ See generally Joseph Raz, National Self-Determination (Chap. 6), Ethics in the Public Domain 125, 120 (1995) ("Group interests are conceptually connected to the interests of their members but such connections are nonreductive and generally indirect"). 
This insight illuminates collective entitlements more generally. Thus, citizen suits concern the citizenry and its entitlements along similar lines. Such a civic community possesses not only an equivalent legal existence, recognized at the very least by the statute that authorizes the action but also rights, which its members may exercise on its behalf ${ }^{114}$. In the pharmaceutical air-contamination example invoked in Part III, the society as a whole exists in this sense and a local activist enforces its environmental entitlements.

Certainly, one need not postulate a metaphysically bizarre communal entity in order to speak of collective entitlements that pertain to a group rather than to its members. One merely has to acknowledge that people may create an institution, such as a corporation, club, town, o state, which may hold rights that indirectly benefit them but that do not belong to them. Frequently, the process of creation unfolds less formally - as with neighborhoods, ethnicities, or nations - and legal recognition may take place ex post facto ${ }^{115}$.

Furthermore, the enforcement of collective rights does not preclude the exercise of individual rights. In fact, the two unfold independently of, even though they may interrelate with and impinge upon, each other. For

${ }^{114}$ For example, section 4911 of the 1972 Noise Control Act expressly authorizes the use of citizen suits in federal court for air noise control violations. See Noise Control Act's Citizen Suit Provision, 42 U.S.C. §4911(b) (2006) (“[A]ny person (other than the United States) may commence a civil action on his own behalf [...]. against any person ... who is alleged to be in violation of any noise control requirement [...]. The district courts of the United States shall have jurisdiction, without regard to the amount in controversy, to restrain such person from violating such noise control requirement").

115 The communal entity, whether formally or informally created, must simply meet the requirements of numerosity, commonality, typicality, and adequate representation in order to attain recognition as class. See Fed. R. Civ. P. 23 (a). If it shows that "the party opposing [it] has acted or refused to act on grounds that apply generally to the class" in violation of its rights, it may request "final injunctive relief or corresponding declaratory relief is appropriate respecting the class as a whole". Fed. R. Civ. P. 23 (b)(2). See also Fed. R. Civ. P. 23 advisory committee's note (1966 Amendment) (Subdivision (b)(2)) ("This subdivision is intended to reach situations where a party has taken action or refused to take action with respect to a class, and final relief of an injunctive nature or of a corresponding declaratory nature, settling the legality of the behavior with respect to the class as a whole, is appropriate"). 
example, a derivative suit to prevent, as corporate waste, a massive bonus for directors would run separately from a shareholder class action to force the distribution of certain overdue dividends, although it may affect the amount of money available for such payments. Similarly, a citizen suit to stop a chemical plant from polluting the air would proceed apart from, but would most likely bear upon, a class action by the neighbors seeking reparation for the depreciation of their property.

Finally, the implementation of group rights need not operate oppressively vis-à-vis the members and their entitlements. As just observed, it involves a different and independent set of rights, which do not belong to the members in the first place. All the same, the exercise of such entitlements may undermine the collectivity's autonomy and, therefore, calls for special judicial control.

In a derivative suit, for instance, the plaintiff enforces the corporation's rights, not her own or those of other stockholders ${ }^{116}$. Nonetheless, the court must ensure that she properly represents the corporative entity in a legitimate act of participatory democracy. It must limit her participation in corporate decision-making to matters open to stockholder direct engagement and otherwise prevent her from neutralizing the duly designated board.

In a citizen suit, the complainant likewise vindicates the rights of the society as a whole, rather than her own or those of her fellow citizens, ${ }^{117}$ as in the previously cited pharmaceutical example. The tribunal must guarantee, however, that she appropriately acts in participatory and democratic representation of the citizenry. It must rely on its own judgment and on the authorities' input, in order to keep her from hampering the work of the political branches of government.

116 See Fed. R. Civ. P. 23.1(a); see also Tooley v Donaldson, Lufkin \& Jenrette, Inc., 845 A2d 1031, 1036 (Del. 2004) ("[The derivative suit] enables a stockholder to bring suit on behalf of the corporation for harm done to the corporation. Because a derivative suit is being brought on behalf of the corporation, the recovery, if any, must go to the corporation"); Levine v. Smith, 591 A.2d 194, 200 (Del. 1991) (“A shareholder derivative suit is a uniquely equitable remedy in which a shareholder asserts on behalf of a corporation a claim belonging not to the shareholder, but to the corporation").

${ }^{117}$ See supra note 113 and accompanying text. 
In both cases, however, the judiciary should avoid granting the democratically elected representatives a prerogative to speak for the collectivity. It should appreciate the value and the legality of alternative modes of representation, whether within the corporation or society as a whole. Litigation should go forward so long as the litigants meet the basic statutory or regulatory prerequisites, even if the pleadings do not demonstrate a clear conflict of interest or a manifest incapacity on the part of the official decision-makers.

On this front, citizen suits might lead derivative suits toward even more openness. The former, as opposed to the latter, do not require the plaintiff to establish, whether in the complaint or at trial, that office holders have compromised themselves ${ }^{118}$. Ideally, derivative suits might follow citizen suits down this path and end up taking a similar approach.

As a result, the complainant in a derivative suit would not need to show that the directors lack independence. She would only have to confirm that she offered them the opportunity to file the action themselves. Such a confirmation would operate to some extent like a showing of exhaustion of administrative remedies in a citizen suit against a governmental agency ${ }^{119}$.

Subsequently, the court would pass on the appropriateness of the board's refusal. It would thereby consider whether further litigation would serve the corporation's best interests. Finally, the judicial focus would turn to the merits of the derivative claim.

118 See supra notes 18, 21-22, 111 and accompanying text.

119 See Hawes v. Oakland, 104 U.S. 450, 460 (1881) ("[B]efore the shareholder is permitted in his own name, to institute and conduct a litigation which usually belongs to the corporation, he should show [...] that he has exhausted all the means within his reach to obtain, within the corporation itself, the redress of his grievances, or action in conformity to his wishes"); see also Aronson v. Lewis, 473 A.2d 805, 811-812 (Del. 1984), overruled on other grounds by Brehm v. Eisner, 746 A.2d 244 (Del. 2000) ("Hence, the demand requirement of Chancery Rule 23.1 exists at the threshold, first to insure that a stockholder exhausts his intracorporate remedies, and then to provide a safeguard against strike suits. Thus, by promoting this form of alternate dispute resolution, rather than immediate recourse to litigation, the demand requirement is a recognition of the fundamental precept that directors manage the business and affairs of corporations."). 
In citizen suits, of course, the government benefits not only from its usually superior financial resources and expertise in the defense of the public interest but also from certain procedural advantages. It must normally receive notice prior to litigation, ${ }^{120}$ in addition to a copy of any eventually proposed consent decree ${ }^{121}$. The authorities may then intervene, ${ }^{122}$ as well as object to any such decree. Moreover, they may request dismissal if they are already "diligently prosecuting an action" on the matter ${ }^{123}$.

In the context of derivative suits, the board presently enjoys many of these procedural benefits, along with others. It ordinarily has a right to notification in the form of a demand on it by the person intending to sue $^{124}$. Additionally, the corporation joins the action as a defendant, ${ }^{125}$ as do the directors if the complaint stakes a claim against them. The corporate leadership therefore participates in the proceedings, as well as in any settlement negotiations. Furthermore, it may move to dismiss the complaint by invoking its own ongoing diligent prosecution, ${ }^{126}$ which would justify the rejection of an additional identical suit and, consequently, terminate the complainant's "legal ability to initiate a derivative action" $" 27$. Finally, at any point prior to the trial, "[...] an

${ }^{120}$ See, e.g., Comprehensive Environmental Response, Compensation, and Liability Act (1980) (CERCLA), 42 U.S.C. § 9659(d)(1), (e) (2006).

${ }^{121}$ See, e.g., Clear Air Act, 42 U.S.C. § 7604(c)(3) (2006) ("No consent judgment shall be entered in an action brought under this section in which the United States is not a party prior to 45 days following the receipt of a copy of the proposed consent judgment by the Attorney General and the Administrator [...]"); Clean Water Act, 33 U.S.C. § 1365(c)(3) (2006) ("No consent judgment shall be entered in an action in which the United States is not a party prior to 45 days following the receipt of a copy of the proposed consent judgment by the Attorney General and the Administrator").

${ }^{122}$ See, e.g., CERCLA, 42 U.S.C. $\$ 9659(\mathrm{~g})$.

${ }^{123}$ See, e.g., id., § 9659(d)(2).

${ }^{124}$ See supra note 15 and accompanying text.

${ }^{125}$ See supra note 77 and accompanying text.

${ }^{126}$ See Maldonado v. Flynn, 413 A.2d 1251, 1263 (Del. Ch. 1980) (“The stockholder's right to litigate is secondary to the corporate right to bring suit only for so long as the corporation has not decided to refuse to bring suit").

127 Zapata Corp. v. Maldonado, 430 A.2d 779, 784 (Del. 1981) (“A demand, when required and refused (if not wrongful), terminates a stockholder's legal ability to initiate 
independent committee possesses the corporate power to seek the termination of a derivative suit" ${ }^{\prime 28}$.

Conversely, citizen suits could evolve too by drawing on the experience with derivative actions. Most conspicuously, they might take a page from the latter with respect to standing. This issue has generated considerable controversy in the literature on citizen suits ${ }^{129}$.

A citizen suit presently demands an "injury in fact," requiring that "the party seeking review be himself among the injured"130. In Arizona Christian School Tuition Organization v. Winn, ${ }^{131}$ the United States Supreme Court explained that "requiring a particular injury" entails " that the injury must affect the plaintiff in a personal and individual way""132. In Bond v. United States, ${ }^{133}$ the justices established the following: "It is not enough that a litigant 'suffers in some indefinite way in common with people generally"'134.

a derivative action").

${ }^{128} \mathrm{Id}$. at 785; see also id. at 788 ("After an objective and thorough investigation of a derivative suit, an independent committee may cause its corporation to file a pretrial motion to dismiss in the Court of Chancery").

${ }^{129}$ See generally, e.g., Daniel A. Farber, A Place-Based Theory of Standing, 55 UCLA L. Rev. 1505 (2008); John A. Ferejohn \& Larry D. Kramer, Independent Judges, Dependent Judiciary: Institutionalizing Judicial Restraint, 77 N.Y.U. L. Rev. 962 (2002); William A. Fletcher, The Structure of Standing, 98 Yale L.J. 221, 223, 229 (1988); Myriam E. Gilles, Representational Standing: U.S. ex rel. Stevens and the Future of Public Law Litigation, 89 Cal. L. Rev. 315 (2001); Edward A. Hartnett, The Standing of the United States: How Criminal Prosecutions Show That Standing Doctrine Is Looking for Answers in All the Wrong Places, 97 Mich. L. Rev. 2239 (1999); Cass R. Sunstein, Informational Regulation and Informational Standing: Akins and Beyond, 147 U. Pa. L. Rev. 613 (1999); Cass R. Sunstein, Standing and the Privatization of Public Law, 88 Colum. L. Rev. 1432, 1434 (1988); Cass R. Sunstein, What's Standing After Lujan? Of Citizen Suits, "Injuries, " and Article III, 91 Mich. L. Rev. 163 (1992); Steven L. Winter, The Metaphor of Standing and the Problem of Self-Governance, 40 Stan. L. Rev. 1371, 1395 (1988).

${ }^{130}$ Sierra Club v. Morton, 405 U.S. 727, 734-735 (1972).

131 131 S. Ct. 1436 (2011).

${ }^{132} I d$. at 1442 (quoting Lujan v. Defenders of Wildlife, 504 U.S. 555, 560 n.1 (1992)).

133131 S. Ct. 2355 (2011).

${ }^{134}$ Id. at 2366 (quoting Frothingham v. Mellon, 262 U.S. 447, 488 (1923) (decided with Massachusetts v. Mellon)). 
Derivative suits, in contrast and more appropriately, rest on the assumption that the complainant does not have a personal stake in the underlying group-claim. If she did, she would be asserting, at best, an aggregation of individual claims. Accordingly, she would need to file a direct action, or perhaps a shareholder class action.

In a genuinely collective suit, the plaintiff does not and cannot have an individual interest. Therefore, judges should not demand that she show the opposite. They should simply ask her to demonstrate that the collectivity has a cognizable claim to which she will do full justice.

In sum, derivative and citizen suits may jointly contribute to clarifying the nature and the inner workings of group entitlements. They may ultimately transform and improve themselves based on such clarification. At the end of the day, other collective actions might equally profit from the new insights.

Ángel R. Oquendo é professor de Direito na University of Connecticut - School of Law.

E-mail: oquendo@uconn.edu.

Endereço professional: University of Connecticut School of Law, 55 Elizabeth Street, Hartford, CT 06105-2290 USA. 